\title{
ZNF385B wt Allele
}

National Cancer Institute

\section{Source}

National Cancer Institute. ZNF385B wt Allele. NCI Thesaurus. Code C158573.

Human ZNF385B wild-type allele is located within 2q31.2-q31.3 and is approximately 420

$\mathrm{kb}$ in length. This allele, which encodes zinc finger protein 385B, may be involved in the regulation of apoptosis. 